\title{
ANALISIS STRATEGI DENGAN METODE SWOT DAN QSPM (QUANTITATIVE STRATEGIC PLANNING MATRIX): STUDI KASUS PADA D'GRUZ CAFFE DI KECAMATAN BLUTO SUMENEP
}

\author{
Ariza Qanita \\ UIN Sunan Ampel Surabaya \\ Email: qanitaariza99@gmail.com
}

\begin{abstract}
Abstrak
Penelitian ini bertujuan untuk menganalisis strategi yang diterapkan pada usaha D'Gruz Caffe sekaligus merumuskan strategi baru dengan memperhatikan faktor internal dan eksternal serta menentukan strategi alternatif yang sebaiknya diprioritaskan. Metode penelitian yang digunakan adalah kualitatif deskriptif dengan teknik analisis menggunakan matriks IFAS-EFAS, matriks IE, matriks SWOT, dan matriks QSPM. Hasil penelitian menunjukkan bahwa D'Gruz Caffe berada pada posisi hold and mantain sehingga strategi yang sebaiknya dilakukan adalah penetrasi pasar dan pengembangan produk. Hasil analisis SWOT merekomendasikan perusahaan harus melakukan strategi Strength-Oppotunity (SO) mencakup tiga alternatif strategi yang kemudian diurutkan dengan matriks QSPM untuk mendapatkan strategi prioritas. Hasil matriks QSPM mengurutkan tiga alternatif strategi yaitu strategi memaksimalkan lokasi yang strategis untuk menarik pangsa pasar potensial dengan skor TAS tertinggi sebesar 4,21, strategi memperbaiki dan menjaga kualitas produk untuk mempertahankan koneksi pelanggan dengan skor TAS sebesar 3,92 serta strategi memberikan diskon dan pelayanan yang baik untuk menjaga loyalitas pelanggan dengan skor TAS sebesar 3,26. Ketiga strategi tersebut menjadi saran manajemen strategi yang bisa dilakukan oleh perusahaan. Strategi yang sebaiknya diprioritaskan oleh perusahaan adalah memaksimalkan lokasi yang strategis untuk menarik pangsa pasar potensial.
\end{abstract}

Kata Kunci: Manajemen Strategi, Matriks IFAS-EFAS, Matriks IE, SWOT, QSPM.

\begin{abstract}
This study aims to analyze the strategies applied in D'Gruz Caffe's business as well as formulating new strategies by taking into account internal and external factors and determining alternative strategies that should be prioritized. The research method used is descriptive qualitative analysis techniques using IFAS-EFAS matrix, IE matrix, SWOT matrix, and QSPM matrix. The results showed that $D^{\prime} G r u z$ Caffe is in a hold and spell position so that the strategy that should be done is market penetration and product development. The result of the SWOT analysis recommends that companies must carry out a Strength-Oppotunity (SO) strategy that includes three alternative strategies which are then sorted by the QSPM matrix to obtain priority strategies. The results of the QSPM matrix rank three alternative strategies: a strategy to maximize strategic location to attract potential market shares with the highest TAS score of 4.21, a strategy to improve and maintain product quality to maintain customer connections with a TAS score of 3.92 and a strategy to provide discounts and services which is good for maintaining customer loyalty with a TAS score of 3.26. These three strategies become management strategy suggestions that can be done by the company. But the strategy recommendations that should be prioritized by companies are to maximize strategic locations to attract potential market share.
\end{abstract}

Keywords: Strategy Management, IFAS-EFAS Matrix, IE Matrix, SWOT, QSPM. 


\section{A. PENDAHULUAN}

Faktor lingkungan turut mempengaruhi perkembangan sebuah usaha atau bisnis. Lingkungan ini meliputi lingkungan internal dan eksternal dari suatu usaha. Lingkungan internal menyangkut lingkungan bisnis dalam perusahaan sendiri seperti produksi, manajemen dan sumber daya manusia, keuangan, pemasaran, dan sebagainya. Sementara lingkungan eksternal terdiri dari berbagai faktor di luar perusahaan yang turut berpengaruh terhadap kelangsungan perusahaan. Lingkungan eksternal dikelompokkan menjadi dua yaitu lingkungan industri dan lingkungan jauh. Lingkungan industri meliputi aspek hambatan masuk, daya tawar pemasok, daya tawar pembeli, ketersediaan barang substitusi dan tingkat persaingan dalam industri. Lingkungan jauh meliputi aspek sosial, budaya, ekonomi, politik, teknologi dan sebagainya. Perubahan yang terjadi pada aspek lingkungan ini dapat berpengaruh pada stabilitas dan keberlanjutan suatu usaha.

Pemilihan strategi yang tepat sangat penting dalam sebuah usaha dengan disesuaikan pada lingkungan bisnis yang dihadapi. Setiap lingkungan bisnis yang berbeda juga membutuhkan strategi yang berbeda. Oleh karena itu, dalam perumusan strategi harus menganalisis terlebih dahulu tentang lingkungan bisnis yang dihadapi baik dari sisi internal maupun eksternal. Analisis strategi bermanfaat bagi manajemen perusahaan dalam membuat keputusan bisnis terutama dalam menghadapi persaingan.

D'Gruz Caffe merupakan sebuah usaha dalam bidang kuliner yang mulai beroperasi pada tahun 2019. Usaha ini menyajikan sebuah tempat makan dengan konsep kekinian dan dekorasi tempat yang menarik. Kafe ini beroperasi setiap hari mulai pukul 10.00 sampai 23.00 WIB. Lokasinya juga sangat strategis dan mudah dijangkau karena dekat dengan jalan utama kecamatan. Usaha ini mengambil segmen usaha di daerah kecamatan karena belum adanya usaha sejenis yang beroperasi di tingkat kecamatan. Usaha ini sangat potensial terutama untuk menarik minat generasi muda dan di sisi lain juga belum ada pesaing dengan usaha sejenis. Namun, dalam beberapa waktu terakhir usaha ini mengalami penurunan omset. Oleh karena itu, sangat diperlukan adanya evaluasi dan perumusan kembali strategi yang tepat sebagai solusi atas permasalahan dalam usaha tersebut dengan memperhatikan kondisi internal dan eksternal yang harus dihadapi.

Permasalahan dalam penelitian ini adalah bagaimana strategi yang sebaiknya diterapkan dalam usaha D'Gruz Caffe dan bagaimana alternatif strategi yang harus diprioritaskan dalam implementasinya pada usaha tersebut. Penelitian ini bertujuan untuk menganalisis strategi yang diterapkan pada usaha D'Gruz Caffe serta merumuskan strategi baru dengan memperhatikan faktor internal dan eksternal sekaligus menentukan strategi alternatif prioritas.

\section{B. KAJIAN PUSTAKA}

\section{Manajemen Strategi}

Manajemen strategi terdiri dari dua kata yaitu manajemen dan strategi. Manajemen dapat diartikan sebagai sebuah ilmu atau seni yang berkaitan dengan aktivitas terpadu untuk mensinergikan berbagai sumber daya yang dimiliki perusahaan seperti sumber daya manusia, sumber daya alam, dan teknologi untuk mencapai tujuan yang diinginkan perusahaan. Sedangkan strategi dapat dipahami sebagai sebuah ilmu tentang perencanaan dan pengarahan. Strategi adalah alat berupa tindakan yang bersifat penting bagi perusahaan dalam bersaing 
untuk mencapai tujuan secara efektif dan efisien dengan memberikan respon terhadap lingkungan internal dan eksternal serta dibutuhkan untuk masa sekarang dan masa yang akan datang (Safitri, 2018).

Hadari Nawawi mengemukakan dua pengertian tentang manajemen strategi yaitu, pertama, manajemen strategi adalah proses atau rangkaian kegiatan pengambilan keputusan yang bersifat mendasar dan menyeluruh, disertai penetapan cara melaksanakannya yang dibuat oleh manajemen puncak dan diimplementasikan oleh seluruh jajaran di suatu organisasi untuk mencapai tujuannya. Kedua, manajemen strategi adalah usaha manajerial menumbuhkembangkan kekuatan organisasi untuk mengeksploitasi peluang yang muncul guna mencapai tujuan yang telah ditetapkan sesuai dengan misi yang telah ditentukan (Sedjati, 2015).

Menurut David, manajemen strategi adalah seni dan pengetahuan untuk merumuskan, mengimplementasikan, dan mengevaluasi keputusan lintas fungsional yang memungkinkan suatu organisasi untuk mencapai tujuannya. Menurut Wheelen dan Hunger, manajemen strategi adalah seperangkat keputusan serta tindakan manajerial yang menentukan kinerja panjang bagi sebuah perusahaan (Oei Venny Febrianti, 2014).

Menurut Eddy Yunus, manajemen strategi adalah suatu rangkaian aktivitas dalam pengambilan keputusan yang bersifat mendasar dan komprehensif disertai dengan penetapan cara aplikasinya yang dibuat oleh pimpinan dan dilaksanakan oleh seluruh pihak yang terlibat dalam perusahaan untuk mencapai tujuan yang diharapkan (Yunus, 2016).

Dengan demikian, manajemen strategi dapat dipahami sebagai sebuah ilmu dan seni untuk menyinergikan berbagai sumber daya yang dimiliki perusahaan (SDM, SDA, teknologi, dan lainnya) secara proporsional sehingga dapat dicapai keputusan stratejik untuk mencapai tujuan perusahaan secara optimal dengan tetap memperhatikan aspek lingkungan. Manajemen strategi biasanya diawali dengan melakukan analisis lingkungan internal dan eksternal perusahaan terlebih dahulu. Manajemen strategi berperan penting untuk meningkatkan kinerja organisasi, meningkatkan laba, menguasai pangsa pasar, menciptakan keunggulan kompetitif, dan meningkatkan hasil pengembalian bagi para pemegang saham (Hery, 2018).

Menerapkan manajemen strategi dalam sebuah perusahaan memiliki manfaat sebagai berikut (Amirullah, 2015):

a. Memberi arah jangka panjang yang akan dituju perusahaan.

b. Membantu perusahaan beradaptasi dengan berbagai perubahan.

c. Membantu perusahaan menjadi lebih efektif.

d. Mengindentifikasi keunggulan komparatif perusahaan dalam lingkungan yang berisiko.

e. Pembuatan strategi membantu perusahaan dalam melakukan pencegahan atas munculnya masalah di masa yang akan dating.

f. Memotivasi karyawan karena keterlibatan mereka dalam pembuatan strategi.

g. Mengurangi aktivitas tumpang tindih.

h. Mengurangi keengganan untuk berubah dari karyawan lama.

Manajemen strategi sudah diperkenalkan sejak dasawarsa enam puluhan meski masih melewati beberapa tahapan. Pada saat itu, manajemen strategi banyak digunakan oleh manajer perusahaan karena dinilai dapat mengurangi ketidak pastian dan semakin kompleksnya perkembangan dalam dunia bisnis. Proses dalam manajemen strategi terdiri dari 
perumusan atau perencanaan strategi (formulating/ strategic planning), pelaksanaan strategi (strategic implementing), dan pengawasan strategi (strategic controlling/evaluating). Manajemen strategi sangat berperan dalam membantu manajemen perusahaan menentukan strategi yang tepat untuk mencapai tujuan usaha yang dijalankan.

Manajemen strategi berbeda dengan manajemen pada umumnya. Manajemen strategi diarahkan untuk menyikapi perubahan lingkungan yang dinamis atau tuntutan peningkatan kinerja organisasi. Menurut Taufiqurohman dalam Efri, manajemen strategi memiliki karakteristik sebagai berikut (Novianto, 2019):

a. Bersifat jangka panjang.

b. Bersifat dinamis.

c. Perlu dimotori oleh unsur-unsur pada manajemen puncak.

d. Berorientasi masa depan.

e. Pelaksanaannya harus didukung oleh semua sumber daya ekonomi yang tersedia. Secara garis besar, tahapan dalam formulasi strategi dibagi menjadi tiga tahap, yaitu:

a. Input Stage (Tahap Masukan). Tahap ini berupa pengumpulan informasi dasar sebelum merumuskan strategi. Proses yang dilakukan adalah menganalisis faktor internal dan eksternal perusahaan yang dapat disajikan dalam matriks IFAS (Internal Factor Assesment Strategy) dan EFAS (Eksternal Factor Assesment Strategy).

b. Matching Stage (Tahap Pemaduan). Tahap ini berupa perumusan berbagai alternatif strategi dengan memadukan berbagai faktor internal dan eksternal yang sudah diperoleh pada tahap sebelumnya. Proses ini dapat dianalisis dalam matriks IE (Internal-Eksternal) dan matriks SWOT (Strength, Weakness, Opportunity, Threats).

c. Decision Stage (Tahap Pemilihan Strategi). Pada tahap ini dilakukan pemilihan strategi yang dirasa paling sesuai dari berbagai alternatif strategi yang sudah diperoleh melalui matriks IE dan matriks SWOT. Berbagai alternatif strategi diurutkan berdasarkan tingkat kepentingannya dengan menggunakan matriks QSPM (Quantitative Strategic Planning Matriks) untuk menentukan prioritas strategi.

\section{Matriks IFAS-EFAS}

Matriks IFAS (Internal Factor Assesment Strategy) dan EFAS (Eksternal Factor Assesment Strategy) digunakan untuk menganalisis faktor internal dan eksternal yang dapat berpengaruh terhadap kelangsungan sebuah bisnis. Matriks IFAS digunakan untuk melakukan penilaian dan pembobotan atas faktor internal yang diperoleh berupa kekuatan dan kelemahan dalam suatu usaha. Sedangkan matriks EFAS digunakan untuk melakukan penilaian dan pembobotan atas faktor eksternal yang berupa peluang dan ancaman.

Pembobotan bertujuan untuk mengkuantifikasi faktor internal dan eksternal dengan skala 1,0 (sangat penting) sampai dengan 0,0 (tidak penting). Akumulasi pembobotan tidak boleh melebihi skor total yaitu 1,0. Sementara untuk pemberian rating menggunakan skala 4 sampai 1. Untuk faktor yang bersifat positif seperti kekuatan dan peluang, semakin besar kekuatan dan peluang maka diberi rating 4 tetapi semakin kecil faktor tersebut maka diberi rating 1. Sedangkan untuk faktor yang bersifat negatif seperti kelemahan dan ancaman berlaku sebaliknya. Semakin besar kelemahan dan ancaman maka diberi rating 1 tetapi jika faktor tersebut semakin kecil maka diberi rating 4. Selanjutnya, pembobotan akan dikalikan 
dengan rating dan dilakukan penjumlahan total untuk mendapatkan skor pembobotan bagi perusahaan yang bersangkutan.

\section{Matriks IE (Internal-Eksternal)}

Matriks IE digunakan untuk merumuskan strategi dengan melihat posisi perusahaan dalam matriks. Matriks ini menggunakan skor total pembobotan IFAS sebagai sumbu X dan skor total pembobotan EFAS sebagai sumbu Y. Gabungan kedua matriks ini menghasilkan matriks internal eksternal yang berisi sembilan sel dengan ketentuan sebagai berikut (I Nengah Widiana Putra, 2019):

a. Sel I, II, dan IV menggambarkan kondisi perusahaan sebagai grow dan build atau tumbuh dan bina. Strategi yang cocok diterapkan adalah intensif yang meliputi penetrasi pasar, pengembangan pasar, dan pengembangan produk atau strategi integrasi yang meliputi integrasi ke depan, integrasi ke belakang dan integrasi horizontal.

b. Sel III, V, dan VII menggambarkan kondisi perusahaan sebagai hold dan maintain atau pertahankan dan pelihara. Strategi yang biasa digunakan adalah penetrasi pasar dan pengembangan produk.

c. Sel VI, VIII, dan IX dapat menggunakan strategi harvest dan divestiture atau panen dan divestasi. Strategi yang biasa dilakukan adalah divestasi strategi, diversifikasi konglomerat, dan melakukan likuidasi.

Posisi perusahaan pada sel tersebut dapat digunakan untuk menentukan perumusan alternatif strategi yang sesuai. Selanjutnya, hasil dari matriks ini dapat dijadikan acuan dalam merumuskan strategi pada matriks SWOT dengan mengkombinasikan faktor kekuatan, kelemahan, peluang dan ancaman yang berkaitan.

\section{Matriks SWOT}

Matriks SWOT digunakan dalam merumuskan strategi dengan mengkombinasikan empat faktor yaitu Strength (kekuatan), Weakness (kelemahan), Opportunity (peluang), dan Threats (ancaman). Empat faktor tersebut mencakup kondisi internal dan eksternal perusahaan. Hasil analisis biasanya berupa arahan atau rekomendasi untuk mempertahankan kekuatan dan memanfaatkan peluang sambil mengurangi kelemahan dan menghindari ancaman.

Analisis SWOT dianggap memiliki banyak manfaat dan kelebihan dibanding metode analisis lain. Manfaat menggunakan analisis SWOT antara lain (Agus Hardiyanto, 2018):

a. Membantu melihat persoalan dari empat sisi sekaligus yaitu kekuatan, kelemahan, peluang dan ancaman.

b. Memberikan hasil analisis yang cukup tajam sehingga dapat memberikan arahan atau rekomendasi untuk mempertahankan kekuatan dan meningkatkan keuntungan dengan memanfaatkan peluang serta mengurangi kelemahan dan menghindari ancaman.

c. Membantu membedah organisasi atau perusahaan dari empat sisi yang menjadi dasar proses identifikasi sehingga dapat menemukan sisi yang kadang terlupakan.

d. Menjadi instrumen yang cukup ampuh dalam melakukan analisis strategi sehingga dapat menemukan langkah terbaik yang sesuai dengan kondisi yang dihadapi.

Matriks analisis SWOT menghasilkan empat elemen strategi dengan mengkombinasikan keempat faktor yang dianalisis. Elemen tersebut terdiri dari SO, WO, ST, 
dan WT. Pertama, Strength-Oppotunity (SO) merupakan strategi untuk memaksimalkan kekuatan internal perusahaan untuk memanfaatkan peluang yang ada sehingga dapat bersaing. Kedua, Weakness-Opportunity (WO) merupakan strategi untuk mengurani kelemahan dengan memanfaatkan peluang. Ketiga, Strength-Threats (ST) merupakan strategi untuk mengurangi atau meminimalkan ancaman dari luar perusahaan dengan memaksimalkan kekuatan yang dimiliki. Keempat, Weakness-Threats (WT) merupakan strategi bertahan dengan mengurangi kelemahan yang dimiliki dan menghindari ancaman dari luar perusahaan (Dhika Amalia Kurniawan, 2019).

Setelah alternatif strategi terbentuk berdasarkan empat set tersebut, maka dilakukan pemilihan strategi yang tepat untuk diterapkan. Untuk mengetahui posisi strategi yang sesuai maka harus dilakukan perhitungan dengan mengakumulasi setiap faktor yang digunakan dalam perumusan strategi. Misalnya untuk menemukan besaran nilai dari strategi SO maka dilakukan penjumlahan dari total pembobotan faktor strength dan opportunity yang sudah ada pada matriks IFAS dan EFAS. Dari keempat set strategi tersebut kemudian dipilih strategi yang memiliki nilai akumulasi tertinggi dari semua elemen strategi yang ada.

\section{Matriks QSPM}

Matriks QSPM atau Quantitative Strategic Planning Matrix merupakan sebuah matriks yang digunakan untuk menganalisis berbagai alternatif strategi yang tersedia untuk mendapatkan strategi prioritas. Alternatif strategi yang dianalisis pada tahap ini adalah strategi yang sudah dihasilkan dalam perumusan melalui analisis sebelumnya dengan memadukan faktor internal dan eksternal. Dengan matriks QSPM, manajemen dapat mengurutkan berbagai strategi yang ada untuk membentuk skala prioritas dalam penerapan strategi.

Perhitungan matriks QSPM adalah dengan memadukan faktor-faktor internal dan eksternal terhadap alternatif strategi yang sudah dirumuskan. Dalam proses ini kembali dilakukan pembobotan, penentuan nilai daya tarik atau Attractiveness Scores (AS), dan Total Attractiveness Scores (TAS). Bobot pada faktor internal dan eksternal disesuaikan dengan bobot yang sudah ada pada matriks IFAS dan EFAS sebelumnya. Nilai AS didefinisikan sebagai angka yang mengindikasikan daya tarik relatif dari masing-masing strategi dari satu set alternatif. Ketentuan penilaian AS berlaku sebagai berikut (Hany Setyorini, 2016):

a. Nilai $1=$ tidak menarik

b. Nilai 2 = agak menarik

c. Nilai 3 = cukup menarik

d. Nilai 4 = sangat menarik

Nilai TAS diperoleh dengan mengkalikan bobot dengan nilai AS. Nilai total TAS kemudian diakumulasi untuk mendapatkan tingkat skor dari berbagai alternatif strategi. Skor tertinggi menentukan strategi yang terbaik untuk diterapkan dalam suatu perusahaan. Namun yang harus diperhatikan dalam analisis ini adalah bahwa QSPM hanya digunakan untuk mengurutkan prioritas strategi dalam satu set alternatif.

\section{METODE PENELITIAN}

Jenis penelitian ini merupakan penelitian deskriptif kualitatif. Objek dalam penelitian ini adalah D’Gruz Caffe yang berlokasi di Kecamatan Bluto Kabupaten Sumenep. Objek ini 
dipilih karena mengalami penurunan omset yang terjadi selama beberapa bulan terakhir. Teknik pengumpulan data dilakukan melalui observasi dan wawancara. Jenis data yang digunakan merupakan data primer berupa hasil wawancara dengan pihak manajemen dan konsumen. Selain itu, penelitian ini juga menggunakan data sekunder yang didapatkan dari studi pustaka melalui jurnal dan buku. Teknik analisis data yang digunakan dalam penelitian ini adalah analisis SWOT (Strength, Weakness, Opportinity, Threats) dan analisis QSPM (Quantitative Strategic Planning Matrix) dengan menggunakan matriks IFAS dan EFAS, matriks IE, matriks, SWOT, dan matriks QSPM.

\section{HASIL DAN PEMBAHASAN}

D'Gruz Caffe merupakan sebuah usaha dalam bidang kuliner yang mulai beroperasi pada tahun 2019. Kafe ini beroperasi setiap hari mulai pukul 10.00 sampai 23.00 WIB. Lokasinya sangat strategis dan mudah dijangkau karena dekat dengan jalan utama kecamatan. Usaha ini mengambil segmen usaha di daerah kecamatan karena belum adanya usaha sejenis yang beroperasi di tingkat kecamatan. Usaha ini sangat potensial terutama untuk menarik minat generasi muda dengan menyajikan konsep kekinian dan belum ada pesaing dengan usaha yang sama.

Modal awal yang dibutuhkan dalam pendirian usaha ini adalah sekitar 150 juta. Tempat usaha menggunakan sistem sewa dengan biaya 15 juta dalam satu tahun. Usaha ini belum memiliki legalitas karena tidak adanya anjuran dari pemerintah setempat terkait legalitas usaha tersebut. Selama satu tahun beroperasi, D'Gruz Caffe sudah memiliki 6 orang karyawan yang terdiri dari 5 orang pada bagian pelayanan dengan sistem shift dan satu orang untuk bagian prepare bahan baku. Namun beberapa karyawan yang ada belum memiliki pengalaman kerja sebelumnya. Untuk produksi, usaha ini sudah memiliki alat produksi yang lengkap dan memiliki agen pemasok untuk bahan baku minuman.

Strategi pemasaran sudah menggunakan promosi melakukan sosial media, beberapa kali memberikan diskon pembelian dan melayani delivery order tapi masih terbatas pada pihak tertentu seperti konsumen-konsumen yang bekerja di kantor. Usaha ini juga sudah memiliki beberapa koneksi pelanggan. Selain itu, usaha ini selalu mengadakan evaluasi produk setiap bulan dengan sistem upgrade menu dan menutup menu-menu yang tidak diminati konsumen. Usaha mengalami peningkatan omset pada musim tertentu seperti bulan puasa. Namun kendala yang harus dihadapi adalah kondisi sosial masyarakat sekitar yang masih tergolong awam dengan usaha sejenis dan harga yang kurang sesuai dengan daya beli masyarakat yang masih rendah.

Proses yang dilakukan dalam penelitian adalah pengumpulan data tentang faktor internal dan eksternal yang meliputi kekuatan, kelemahan, peluang dan ancaman. Data yang diperoleh kemudian dianalisis dengan matriks IFAS dan EFAS, matriks IE, matriks SWOT, dan matriks QSPM dengan hasil sebagai berikut: 
ARTIKEL

\begin{tabular}{|c|c|c|c|c|}
\hline \multicolumn{5}{|c|}{ Tabel 1 Matriks IFAS } \\
\hline Faktor Internal & Bobot & Rating & $\begin{array}{l}\text { Bobot } x \\
\text { Rating }\end{array}$ & Komentar \\
\hline $\begin{array}{l}\text { Kekuatan: } \\
\text { 1. Lokasi strategis } \\
\text { 2. Fasilitas lengkap dan } \\
\text { tempat yang nyaman } \\
\text { 3. Alat produksi lengkap } \\
\text { 4. Evaluasi dan inovasi } \\
\text { produk } \\
\text { 5. Diskon, promosi sosial } \\
\text { media dan melayani } \\
\text { delivery order }\end{array}$ & $\begin{array}{l}0,13 \\
0,09 \\
0,13 \\
0,09\end{array}$ & $\begin{array}{l}4 \\
3\end{array}$ & $\begin{array}{l}0,52 \\
0,27 \\
0,52 \\
0,27 \\
0,16 \\
\\
\\
\mathbf{1 , 7 4}\end{array}$ & $\begin{array}{l}\text { 1. Mudah dijangkau } \\
\text { 2. Bersih dan dekorasi } \\
\text { yang eyecatching } \\
\text { 3. Memudahkan proses } \\
\text { produksi } \\
\text { 4. Lebih menyesuaikan } \\
\text { minat konsumen } \\
\text { 5. Meningkatkan penjualan }\end{array}$ \\
\hline $\begin{array}{l}\text { Kelemahan: } \\
\text { 1. Keuangan belum stabil } \\
\text { 2. SDM Karyawan kurang } \\
\text { berpengalaman } \\
\text { 3. Produk tidak konsisten } \\
\text { 4. Pelayanan kasir masih } \\
\text { manual } \\
\text { 5. Harga }\end{array}$ & $\begin{array}{l}0,12 \\
0,10 \\
0,10 \\
0,07 \\
0,09\end{array}$ & $\begin{array}{l}2 \\
4\end{array}$ & $\begin{array}{l}0,12 \\
0,30 \\
0,20 \\
0,28 \\
0,18\end{array}$ & $\begin{array}{l}\text { 1. Omset mengalami } \\
\text { penurunan } \\
\text { 2. Pelayanan kurang } \\
\text { maksimal } \\
\text { 3. Selalu berubah-rubah } \\
\text { karena sistem upgrade } \\
\text { menu } \\
\text { 4. Belum menggunakan } \\
\text { teknologi } \\
\text { 5. Kurang sesuai dengan } \\
\text { daya beli masyarakat }\end{array}$ \\
\hline Total & 1,00 & & 2,82 & \\
\hline
\end{tabular}

Sumber: Data Diolah, 2020

Tabel 2 Matriks EFAS

\begin{tabular}{|c|c|c|c|c|}
\hline Faktor Eksternal & Bobot & Rating & $\begin{array}{l}\text { Bobot } x \\
\text { Rating }\end{array}$ & Komentar \\
\hline $\begin{array}{l}\text { Peluang: } \\
\text { 1. Belum ada pesaing } \\
\text { dengan usaha sejenis } \\
\text { 2. Memiliki koneksi } \\
\text { pelanggan } \\
\text { 3. Sudah memiliki agen } \\
\text { pemasok } \\
\text { 4. Pangsa } \\
\text { potensial pasar } \\
\text { 5. Perubahan gaya hidup } \\
\text { dan musim }\end{array}$ & $\begin{array}{l}0,14 \\
0,13 \\
0,10 \\
0,09 \\
0,07\end{array}$ & 4 & $\begin{array}{l}0,56 \\
0,52 \\
0,30 \\
0,27 \\
0,14 \\
\mathbf{1 , 7 9}\end{array}$ & $\begin{array}{l}\text { 1. Potensi yang } \\
\text { tinggi } \\
\text { 2. Loyalitas } \\
\text { 3. Memudahkan } \\
\text { produksi } \\
\text { 4. Segmen generasi } \\
\text { muda yang } \\
\text { konsumtif } \\
\text { 5. Peningkatan } \\
\text { omset pada waktu } \\
\text { tertentu, misal } \\
\text { bulan puasa }\end{array}$ \\
\hline $\begin{array}{l}\text { Ancaman: } \\
\text { 1. Kondisi } \\
\text { masyarakat }\end{array}$ & 0,11 & 2 & 0,22 & $\begin{array}{l}\text { 1. Masih } \\
\text { dengan }\end{array}$ \\
\hline
\end{tabular}


ARTIKEL

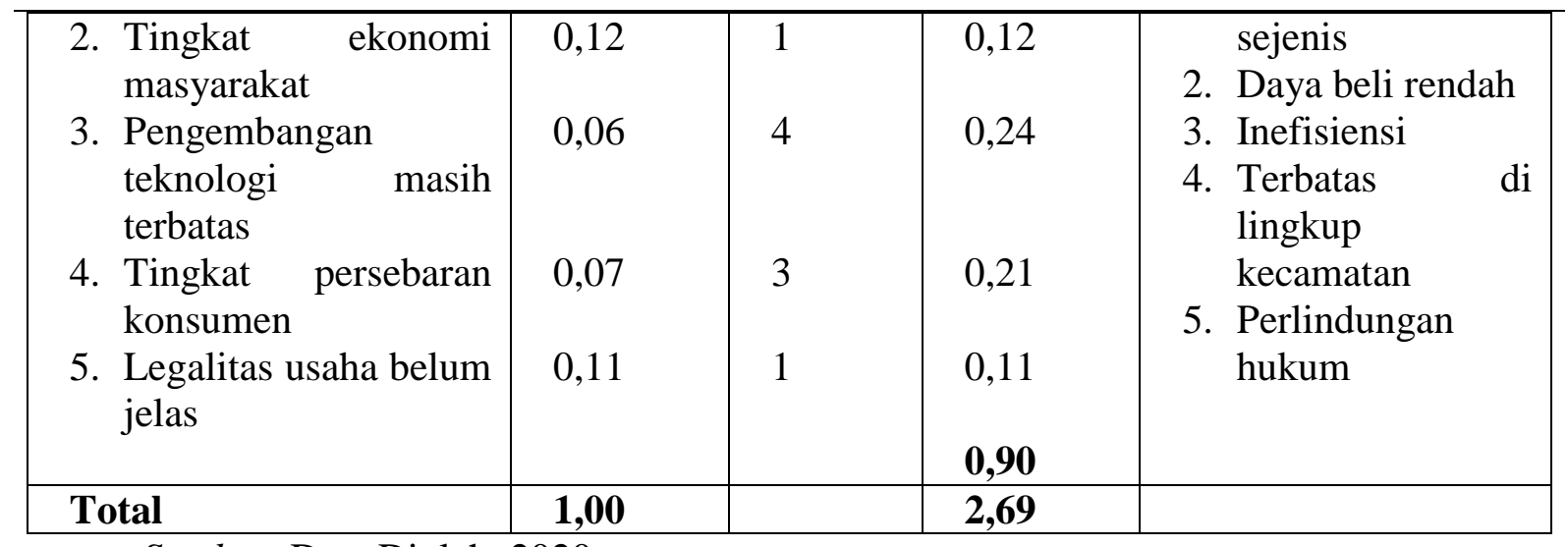

Sumber: Data Diolah, 2020

Analisis faktor internal dengan IFAS mendapatkan skor kekuatan sebesar 1,74 dan skor kelemahan sebesar 1,08 sehingga total skor matriks IFAS adalah 2,82. Sedangkan analisis faktor eksternal dengan EFAS mendapatkan skor peluang sebesar 1,79 dan skor ancaman sebesar 0,90 sehingga total skor matriks EFAS adalah 2,69. Selanjutnya, total skor kedua matriks ini digunakan untuk mengetahui posisi dan strategi perusahaan pada matriks IE.

Tabel 3 Matriks IE

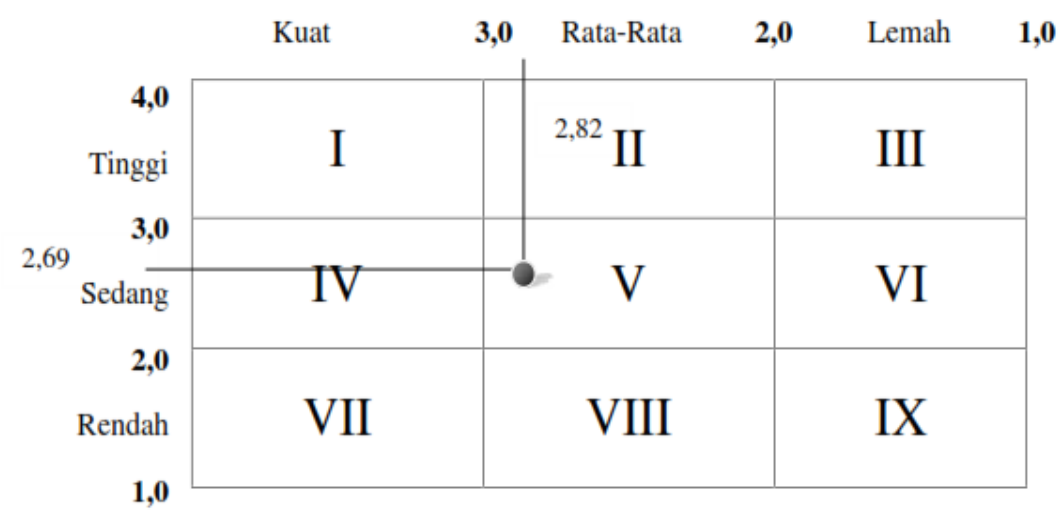

Sumber: Data Diolah, 2020

Matriks IE (Internal-Eksternal) menggunakan total skor IFAS sebagai sumbu X dan total skor EFAS sebagai sumbu Y untuk menunjukkan posisi perusahaan pada sembilan sel yang ada. Total skor IFAS sebesar 2,82 dan total skor EFAS sebesar 2,69 menunjukkan posisi perusahaan berada pada sel $\mathrm{V}$ yang berarti hold and maintain atau pertahankan dan pelihara. Strategi yang sering digunakan untuk kondisi ini adalah penetrasi pasar dan pengembangan produk. Strategi ini kemudian menjadian acuan untuk perumusan alternative strategi pada matriks SWOT.

Tabel 4 Matriks SWOT

\begin{tabular}{|l|l|l|}
\hline \multirow{4}{*}{} & Strength (Kekuatan) & Weakness (Kelemahan) \\
\cline { 2 - 3 } IFAS & $\begin{array}{l}\text { 1. } \\
\text { 2. Alasi strategis }\end{array}$ & 1. Produk tidak konsisten \\
EFAS & $\begin{array}{l}\text { 3. Evaluasi dan inovasi } \\
\text { produk Harga }\end{array}$ & \\
& $\begin{array}{l}\text { Diskon, promosi sosial } \\
\text { media dan melayani }\end{array}$ & \\
\hline
\end{tabular}


ARTIKEL

\begin{tabular}{|c|c|c|}
\hline & delivery order & \\
\hline $\begin{array}{l}\text { Opportunity } \\
\text { (Peluang) } \\
\text { 1. Belum ada } \\
\text { pesaing dengan } \\
\text { usaha sejenis } \\
\text { 2. } \begin{array}{l}\text { Memiliki } \\
\text { koneksi } \\
\text { pelanggan } \\
\text { 3. Pangsa pasar } \\
\text { potensial }\end{array}\end{array}$ & $\begin{array}{ll}\text { Strategi SO: } & \\
\text { 1. } & \text { Memaksimalkan lokasi } \\
\text { yang strategis untuk } & \text { pasar } \\
\text { menarik pangsa } & \\
\text { potensial } & \\
\text { 2. } & \text { Memperbaiki dan } \\
& \text { menjaga kualitas produk } \\
& \text { untuk mempertahankan } \\
& \text { koneksi pelanggan } \\
\text { 3. } & \text { Memberikan diskon dan } \\
\text { pelayanan yang baik } \\
\text { untuk menjaga loyalitas } \\
\text { pelanggan }\end{array}$ &  \\
\hline $\begin{array}{l}\text { Threats } \\
\text { (Ancaman) } \\
\text { 1. Kondisi sosial } \\
\text { masyarakat } \\
\text { 2. Tingkat } \\
\text { ekonomi } \\
\text { masyarakat } \\
\text { 3. Tingkat } \\
\text { persebaran } \\
\text { konsumen }\end{array}$ & $\begin{array}{ll}\text { Strategi ST: } & \\
\text { 1. } & \text { Memaksimalkan lokasi } \\
& \text { yang strategis untuk } \\
& \text { meningkatkan persebaran } \\
& \text { konsumen } \\
\text { 2. } & \text { Menggencarkan } \\
& \text { pemasaran } \\
& \text { pengenalan produk pada } \\
& \text { masyarakat } \\
\text { 3. } & \text { Memberikan diskon } \\
& \text { untuk } \\
& \text { masyarakat denarik } \\
& \text { tingkat ekonomi rendah }\end{array}$ & $\begin{array}{ll}\text { Strategi WT: } \\
\text { 1. } \\
\text { Menjaga konsistensi } \\
\text { produk agar mudah } \\
\text { dikenali masyarakat atau } \\
\text { konsumen } \\
\text { 2. } \\
\text { Menyesuaikan harga } \\
\text { dengan tingkat ekonomi } \\
\text { masyarakat } \\
\text { 3. } \\
\text { Melakukan penurunan } \\
\text { harga untuk } \\
\text { meningkatkan } \\
\text { persebaran konsumen }\end{array}$ \\
\hline
\end{tabular}

Sumber: Data Diolah, 2020

Matriks SWOT digunakan untuk merumuskan strategi dengan mengkombinasikan faktor kekuatan, kelemahan, peluang dan ancaman. Faktor yang dijadikan dasar perumusan kombinasi strategi ini adalah faktor yang dapat mempengaruhi strategi penetrasi pasar dan pengembangan produk sesuai yang dihasilkan dari matriks IE. Dalam matriks SWOT dihasilkan empat set strategi yaitu SO, WO, ST, dan WT. Untuk menentukan set strategi yang sesuai dengan perusahaan dari berbagai alternatif yang ada, maka harus dilakukan akumulasi dari kombinasi faktor yang terkait.

Tabel 4 Matrik Perencanaan Kombinasi Strategi SWOT

\begin{tabular}{|c|c|c|}
\hline $\begin{array}{l}\text { IFAS } \\
\text { EFAS }\end{array}$ & Strength (Kekuatan) & Weakness (Kelemahan) \\
\hline $\begin{array}{l}\text { Opportunity } \\
\text { (Peluang) }\end{array}$ & $\begin{array}{l}\text { Strategi SO: } \\
\text { Menggunakan kekuatan untuk } \\
\text { memanfaatkan peluang }=3,53\end{array}$ & $\begin{array}{l}\text { Strategi WO: } \\
\text { Meminimalkan kelemahan } \\
\text { dengan } \quad \text { memanfaatkan } \\
\text { peluang }=2,87\end{array}$ \\
\hline $\begin{array}{l}\text { Threats } \\
\text { (Ancaman) }\end{array}$ & $\begin{array}{l}\text { Strategi ST: } \\
\text { Menggunakan kekuatan untuk } \\
\text { mengatasi ancaman }=2,64\end{array}$ & $\begin{array}{l}\text { Strategi WT: } \\
\text { Meminimalkan kelemahan } \\
\text { dan menghindari ancaman = } \\
1,98\end{array}$ \\
\hline
\end{tabular}

Sumber: Data Diolah, 2020 
Dari matriks kombinasi strategi dihasilkan skor terbesar adalah strategi StrengthOpportunity (SO) dengan total 3,53. Hal ini berarti set strategi yang sebaiknya digunakan oleh perusahaan adalah strategi SO yaitu dengan menggunakan kekuatan untuk memanfaatkan peluang. Strategi SO meliputi memaksimalkan lokasi yang strategis untuk menarik pangsa pasar potensial, memperbaiki dan menjaga kualitas produk untuk mempertahankan koneksi pelanggan, serta memberikan diskon dan pelayanan yang baik untuk menjaga loyalitas pelanggan.

Satu set strategi SO memiliki tiga alternatif strategi. Dalam hal ini analisis menggunakan matriks QSPM bertujuan untuk mengurutkan berbagai alternatif strategi tersebut untuk menemukan prioritas strategi. Hasil dari analisis matriks QSPM dalam penelitian ini adalah sebagai berikut:

Tabel 4 Matriks QSPM

\begin{tabular}{|c|c|c|c|c|c|c|c|}
\hline \multirow{2}{*}{ Faktor Internal \& Eksternal } & \multirow{2}{*}{ Bobot } & \multicolumn{2}{|c|}{ Strategi 1} & \multicolumn{2}{|c|}{ Strategi 2} & \multicolumn{2}{|c|}{ Strategi 3} \\
\hline & & $\mathbf{A S}$ & TAS & $\mathbf{A S}$ & TAS & $\mathbf{A S}$ & TAS \\
\hline \multicolumn{8}{|l|}{ Strength: } \\
\hline 1. Lokasi strategis & 0,13 & 4 & 0,52 & 1 & 0,13 & 1 & 0,13 \\
\hline $\begin{array}{l}\text { 2. Fasilitas lengkap dan } \\
\text { tempat yang nyaman }\end{array}$ & 0,09 & - & 0,39 & - & 0,52 & - & \\
\hline 3. Alat produksi lengkap & 0,13 & 3 & 0,18 & 4 & 0,36 & 3 & 0,39 \\
\hline $\begin{array}{l}\text { 4. Evaluasi dan inovasi } \\
\text { produk }\end{array}$ & 0,09 & 2 & & 4 & & 2 & 0,18 \\
\hline $\begin{array}{l}\text { 5. Diskon, promosi sosial } \\
\text { media dan melayani } \\
\text { delivery order }\end{array}$ & 0,08 & 4 & 0,32 & 3 & 0,24 & 4 & 0,32 \\
\hline \multicolumn{8}{|l|}{ Weakness: } \\
\hline 1. Keuangan belum stabil & 0,12 & - & & - & & - & \\
\hline $\begin{array}{l}\text { 2. SDM Karyawan kurang } \\
\text { berpengalaman }\end{array}$ & 0,10 & - & & - & & - & \\
\hline 3. Produk tidak konsisten & 0,10 & 3 & 0,30 & 4 & 0,40 & 3 & 0,30 \\
\hline $\begin{array}{l}\text { 4. Pelayanan kasir masih } \\
\text { manual }\end{array}$ & 0,07 & - & & - & & - & \\
\hline 5. Harga & 0,09 & 2 & 0,18 & 2 & 0,18 & 4 & 0,36 \\
\hline \multicolumn{8}{|l|}{ Opportunity: } \\
\hline $\begin{array}{l}\text { 1. Belum ada pesaing } \\
\text { dengan usaha sejenis }\end{array}$ & 0,14 & 4 & 0,56 & 4 & 0,56 & 2 & 0,28 \\
\hline $\begin{array}{l}\text { 2. Memiliki koneksi } \\
\text { pelanggan }\end{array}$ & 0,13 & 3 & 0,39 & 4 & 0,52 & 3 & 0,39 \\
\hline $\begin{array}{l}\text { 3. Sudah memiliki agen } \\
\text { pemasok }\end{array}$ & 0,10 & - & & - & & - & \\
\hline 4. Pangsa pasar potensial & 0,09 & 4 & 0,36 & 2 & 0,18 & 2 & 0,18 \\
\hline $\begin{array}{l}\text { 5. Perubahan gaya hidup } \\
\text { dan musim }\end{array}$ & 0,07 & - & & - & & - & \\
\hline \multicolumn{8}{|l|}{ Threats: } \\
\hline $\begin{array}{ll}\text { 1. Kondisi } & \text { sosial } \\
\text { masyarakat } & \end{array}$ & 0,11 & 4 & 0,44 & 3 & 0,33 & 1 & 0,11 \\
\hline $\begin{array}{l}\text { 2. Tingkat ekonomi } \\
\text { masyarakat }\end{array}$ & 0,12 & 3 & 0,36 & 3 & 0,36 & 4 & 0,48 \\
\hline 3. Pengembangan & 0,06 & - & & - & & & \\
\hline
\end{tabular}


ARTIKEL

\begin{tabular}{|c|c|c|c|c|c|c|c|c|}
\hline 5. & $\begin{array}{l}\text { teknologi masih } \\
\text { terbatas } \\
\text { Tingkat persebaran } \\
\text { konsumen } \\
\text { Legalitas usaha belum } \\
\text { jelas }\end{array}$ & $\begin{array}{l}0,07 \\
0,11\end{array}$ & 3 & 0,21 & 2 & 0,14 & $\begin{array}{l}2 \\
-\end{array}$ & 0,14 \\
\hline Total & & & & 4,21 & & 3,92 & & 3,26 \\
\hline
\end{tabular}

Sumber: Data Diolah, 2020

Hasil dari matriks QSPM menunjukkan strategi 1 memiliki skor tertinggi sebesar 4,21, diikuti strategi 2 sebesar 3,92 dan strategi 3 sebesar 3,26. Dengan demikian, urutan strategi yang sebaiknya dilakukan oleh perusahaan adalah sebagai berikut:

a. Memaksimalkan lokasi yang strategis untuk menarik pangsa pasar potensial.

Lokasi D'Gruz Caffe yang dekat dengan jalan utama kecamatan menjadi salah satu kekuatan yang bisa digunakan untuk menarik konsumen karena sangat mudah dijangkau. Hal ini sangat membantu terutama untuk menarik pangsa pasar potensial yang terdiri dari generasi muda yang notabene memiliki sifat konsumtif, terlebih belum adanya pesaing yang menawarkan konsep sejenis. Dekorasi ruang juga sudah disesuaikan dengan konsep kekinian yang disukai generasi muda.

b. Memperbaiki dan menjaga kualitas produk untuk mempertahankan koneksi pelanggan.

Memperbaiki dan menjaga kualitas produk sangat penting dilakukan untuk mempertahankan koneksi pelanggan yang dimiliki D'Gruz Caffe terutama dalam konsistensi produk. Pengembangan produk selalu dilakukan melalui sistem upgrade menu dengan evaluasi menu setiap bulan. Dalam hal ini, menu yang tidak diminati akan diclose atau pun melakukan penambahan menu baru. Di satu sisi, sistem ini bermanfaat untuk efisiensi produksi. Namun di sisi lain, hal ini menyebabkan menu yang disajikan terkesan tidak konsisten dan akan menimbulkan kekecewaan bagi pelanggan yang menginginkan menu yang sudah diclose. Strategi ini memberikan saran agar D'Gruz Caffe lebih konsisten dengan menu yang disajikan dan menjaga kualitasnya untuk mempertahankan pelanggan.

c. Memberikan diskon dan pelayanan yang baik untuk menjaga loyalitas pelanggan

Strategi ini penting diterapkan untuk menjaga loyalitas pelanggan D'Gruz Caffe. Pemberian diskon atau potongan harga terhadap pelanggan akan membuat mereka tertarik untuk melakukan pembelian ulang. Selain itu, pelayanan yang baik juga harus dilakukan untuk menciptakan customer satisfaction. Hal ini harus diperhatikan karena kepuasan dan penilaian konsumen tidak hanya mengenai produk yang disajikan melainkan juga kualitas pelayanan yang diberikan. Salah satu bentuk pelayanan yang diberikan dalam D'Gruz Caffe adalah sistem delivery order namun masih terbatas pada pihak-pihak tertentu. Ke depannya, sistem delivery order dapat diperluas sehingga dapat dinikmati oleh berbagai kalangan. Bimbingan terhadap karyawan juga diperlukan untuk menjaga kualitas pelayanan mengingat sebagian besar karyawan yang ada belum memiliki pengalaman sebelumnya. 


\section{E. KESIMPULAN}

Penerapan manajemen strategi sangat penting bagi sebuah usaha atau bisnis dalam rangka mencapai tujuan yang diharapkan. Dengan manajemen strategi, aktivitas bisnis akan lebih terarah serta menyesuaikan dengan perkembangan bisnis yang semakin kompleks. Proses dalam manajemen strategi meliputi perumusan atau perencanaan strategi (formulating/ strategic planning), pelaksanaan strategi (strategic implementing), dan pengawasan strategi (strategic controlling/evaluating).

Untuk membuat formulasi strategi terdapat tiga tiga tahap, yaitu Input Stage (Tahap Masukan) yang dilakukan dengan menganalisis faktor internal dan eksternal melalui matriks IFAS dan EFAS, Matching Stage (Tahap Pemaduan) yang dilakukan dengan merumuskan alternative strategi berdasarkan matriks IE dan matriks SWOT, serta Decision Stage (Tahap Pemilihan Strategi) yang dilakukan dengan mengkuantifikasi berbagai pilihan strategi yang ada melalui matriks QSPM.

Hasil penelitian menunjukkan total skor matriks IFAS adalah 2,82 dan total skor matriks EFAS adalah 2,69 sehingga memposisikan perusahaan pada sel V matriks IE yang berarti berada dalam kondisi hold and maintain. Strategi yang biasa digunakan adalah penetrasi pasar dan pengembangan produk. Selanjutnya dilakukan perumusan alternatif strategi dengan matriks SWOT. Hasil analisis matriks SWOT merekomendasikan perusahaan untuk menerapkan strategi SO. Alternatif strategi yang ada dalam satu set strategi SO dikuantifikasi melalui matriks QSPM. Hasil analisis QSPM menunjukkan bahwa strategi memaksimalkan lokasi yang strategis untuk menarik pangsa pasar potensial memiliki skor TAS tertinggi sebesar 4,21, strategi memperbaiki dan menjaga kualitas produk untuk mempertahankan koneksi pelanggan memiliki skor TAS sebesar 3,92 serta strategi memberikan diskon dan pelayanan yang baik untuk menjaga loyalitas pelanggan memiliki skor TAS sebesar 3,26. Dengan demikian, rekomendasi strategi yang sebaiknya diterapkan oleh perusahaan adalah memaksimalkan lokasi yang strategis untuk menarik pangsa pasar potensial.

Saran untuk penelitian selanjutnya bisa menggunakan metode analisis lain dalam penentuan alternatif strategi prioritas seperti analisis Poter Five Forces, PEST (Politic, Economic, Social and Teknology), Value Chain, Balanced Scorecard, Critical Succes Factor (CSF), Boston Consulting Group (BCG), Analytical Hierarchy Process (AHP), atau Rapid Application Development (RAD).

\section{DAFTAR PUSTAKA}

Agus Hardiyanto, I. S. (2018). Analisis Strategi Pembangunan Desa Wisata di Sentra Pengrajin Keris. OPSI-Jurnal Optimasi Sistem Industri , 11 (1), 1-13.

Amirullah. (2015). Manajemen Strategi Teori-Konsep-Kerja. Jakarta: Mitra Wacana Media.

Dhika Amalia Kurniawan, M. Z. (2019). Strategi Pengembangan Wisata Kampoeng Durian Desa Ngrogung Kecamatan Ngebel Ponorogo Melalui Analisis Matriks IFAS dan EFAS. Al-Tijarah , 5 (2), 93-103.

Hany Setyorini, M. E. (2016). Analisis Strategi Pemasaran Menggunakan Matriks SWOT dan QSPM (Studi Kasus:Restoran WS Soekarno Hatta Malang). Industria: Jurnal Teknologi dan Manajemen Agroindustri , 5 (1), 46-53.

Hery. (2018). Manajemen Strategik. Jakarta: PT. Grasindo. 


\section{ARTIKEL}

I Nengah Widiana Putra, B. P. (2019). Perumusan Strategi Pemasaran Bali Ragam Busana Dengan Metode Quantitative Strategic Planning Matrix (QSPM). e-proceeding of engineering , 6 (2), 7317-7324.

Novianto, E. (2019). Manajemen Strategis. Yogyakarta: Penerbit Deepublish.

Oei Venny Febrianti, M. S. (2014). Usulan Alternatif Strategi PT. X Menggunakan Quantitative Strategic Planning Matrix (QSPM). E-Journal Graduate Unpar , 1 (1), $1-12$.

Safitri, D. (2018). Penggunaan Quantitative Strategic Planning Matrix (QSPM) Untuk Penentuan Alternatif Strategi Prioritas Bisnis Tapis (Studi Pada UMKM Tapis Ruwa Jurai Bandar Lampung). Skripsi, Universitas Lampung, Bandar Lampung.

Sedjati, R. S. (2015). Manajemen Strategis. Yogyakarta: Penerbit Deepublish.

Yunus, E. (2016). Manajemen Strategis. Yogyakarta: Penerbit Andi. 